\title{
Exploring Alzheimer Molecular Pathology in Down's Syndrome Cerebrospinal Fluid
}

\author{
Erik Portelius $^{\mathrm{a}}$ Hilkka Soininen $^{\mathrm{b}}$ Ulf Andreasson $^{\mathrm{a}}$ Henrik Zetterberg ${ }^{\mathrm{a}, \mathrm{c}}$ \\ Rita Persson $^{a}$ Gösta Karlsson $^{a}$ Kaj Blennow ${ }^{a}$ Sanna-Kaisa Herukka ${ }^{b}$ \\ Niklas Mattsson ${ }^{a, d}, \mathrm{e}$
}

anstitute of Neuroscience and Physiology, Department of Psychiatry and Neurochemistry, The Sahlgrenska Academy at the University of Gothenburg, Gothenburg, Sweden; ${ }^{b}$ Department of Neurology, University of Eastern Finland and Kuopio University Hospital, Kuopio, Finland; ' Department of Molecular Neuroscience, UCL Institute of Neurology, London, UK; ${ }^{\mathrm{d}}$ San Francisco VA Medical Center, Center for Imaging of Neurodegenerative Diseases, and ${ }^{\mathrm{e}}$ Department of Radiology and Biomedical Imaging, University of California, San Francisco, Calif., USA

\section{Key Words}

Down's syndrome - Alzheimer's disease - Orexin-A .

Amyloid- $\beta \cdot$ YKL-40 $\cdot$ Tau

\section{Abstract}

Background: Individuals with Down's syndrome (DS) develop early Alzheimer's disease (AD) with $\beta$-amyloid $(A \beta)$ plaque pathology. The extra amyloid precursor protein (APP) gene copy in DS is believed to result in a $50 \%$ increase in A $\beta$ production, but it is unclear how this relates to the development of other AD hallmarks, including axonal degeneration and microglia cell activation, and to other neurological problems in DS, including disturbed sleep regulation. Objective: To evaluate if cerebrospinal fluid (CSF) biomarkers for cerebral amyloidosis, axonal degeneration, microglial activation and sleep regulation were altered in young and old patients with $D S$, and if these biomarkers were related to altered $A \beta$ and APP metabolism, reflected by CSF levels of different $A \beta$ and APP peptides. Methods: CSF from DS patients $(n=12)$ and healthy controls $(n=20)$ were analyzed for $A \beta$ peptides $(A \beta 1-42, A \beta X-38 / 40 / 42)$, secreted APP species (sAPPa/ $\beta$ ), biomarkers for $A D$-like axonal degeneration [total tau (T- tau), phosphorylated tau], microglial activation (YKL-40, CC chemokine ligand 2) and orexin-A, which is a peptide involved in sleep regulation. We compared biomarker levels between groups and tested for relations between biomarkers, disease stage and age. Results: Several of the markers were specifically increased in DS, including $A \beta X-40$, sAPPa and $S A P P \beta$. Orexin- $A$ was significantly decreased in DS and correlated with $A \beta$ and SAPP. Orexin-A decreased with age in DS, while T-tau and YKL-40 increased with age. Conclusion: Down's patients have increased APP and A $\beta$ production and increased microglial activation with age. The orexin-A metabolism is disturbed in DS and may be linked to APP and $A \beta$ production. Biomarker studies of DS may contribute to our understanding of the amyloidogenic and neurodegenerative process in $A D$.

(c) 2014 S. Karger AG, Basel

\section{Introduction}

Down's syndrome (DS), caused by trisomy 21, is one of the most common genetic birth defects and was first described by Down [1] in 1866. DS leads to the develop-

\section{KARGER}

E-Mail karger@karger.com

www.karger.com/ndd
(C) 2014 S. Karger AG, Basel

$1660-2854 / 14 / 0142-0098 \$ 39.50 / 0$
Erik Portelius

Department of Psychiatry and Neurochemistry

Sahlgrenska University Hospital/Mölndal

SE-431 80 Mölndal (Sweden)

E-Mail erik.portelius@ @ neuro.gu.se 
ment of amyloid- $\beta$ (A $\beta$ ) plaque pathology, likely due to the extra copy of the amyloid precursor protein $(A P P)$ gene on chromosome 21. A $\beta$ accumulation has been found in DS individuals from 8 to 12 years of age $[2,3]$. Later in life, DS is associated with an increased risk of Alzheimer's disease $(\mathrm{AD})[4,5]$, which is a dementing illness characterized by the presence of $A \beta$ plaques, neurofibrillary tangles, axonal degeneration and microglial cell activation in the brain [6]. In addition, autopsy studies have found that nearly all DS adults over 35-40 years have both neurofibrillary tangles and plaques [7].

The localization of the APP gene to chromosome 21 [8-10] and the association of $A \beta$ pathology with both $A D$ and DS were important for the development of the amyloid cascade hypothesis, which states that a disturbance in the $\mathrm{A} \beta$ homeostasis is the causal factor in the neuronal degeneration characteristic of $\mathrm{AD}[11]$. However, it is not known how developments of different disease hallmarks are linked to $A \beta$ pathology in DS. Also, it is not known how $A \beta$ pathology is related to other neurological problems in DS, including disturbed sleep regulation [12-14]. To gain insight into these molecular mechanisms, we tested if cerebrospinal fluid (CSF) biomarkers related to $\mathrm{A} \beta$ and APP metabolism (A $\beta$ peptides and APP species), axonal injury [total tau (T-tau) and phosphorylated tau (P-tau)], microglial activation [chitinase-3-like protein 1 (YKL-40) and CC chemokine ligand 2 (CCL2)] and sleep regulation (orexin-A) differed between controls and DS patients. We also tested if biomarker levels differed across the age span in DS. We hypothesized that we would find biomarker evidence of increased $A \beta 42$ production in younger DS patients, as well as AD-like alterations indicating $A \beta$ plaque formation, axonal degeneration, plaque pathology and microglial activation in older DS patients.

The 42 -amino acid $A \beta$ variant $A \beta 1-42$ is a useful biomarker to identify $\mathrm{AD}$ patients and study $\mathrm{AD}$ pathology $[15,16]$. Previous studies have shown that young DS patients have higher CSF concentrations of $A \beta 1-42$ than older DS patients [17] and that middle-aged DS patients have decreased $A \beta 1-42$ compared to controls [18]. Thus, A $\beta 1-42$ seems to be elevated in the early stages of DS and decrease with age, which may reflect development of plaque pathology with plaques acting as peptide sinks in the brain. We tested if we could replicate previous findings of increased CSF $A \beta 1-42$ in young DS patients.

A variety of $A \beta$ peptides are generated from the transmembrane APP protein through sequential cleavage by $\beta$-and $\gamma$-secretase [19]. APP is first cleaved by $\beta$-secretase at the $\mathrm{N}$ terminus, generating a soluble APP fragment (sAPP $\beta$ ) and the membrane-bound fragment C99, which can be further processed by $\gamma$-secretase into various $A \beta$ peptides including $A \beta 1-38, A \beta 1-40$ and $A \beta 1-42$ [20]. In the $\alpha$-secretase pathway, $\alpha$-secretase cleaves APP, generating sAPP $\alpha$ [21]. We extended previous DS studies by measuring several $A \beta$ peptides ( $A \beta 1-42, A \beta X-38 / 40 / 42$ ) and sAPP species (sAPPa and sAPP $\beta$ ) in young and old DS patients to test whether they reflect early disease development.

One previous study on DS patients showed a significant correlation between age and CSF tau, with lower concentrations of tau in the youngest individuals, suggesting that axonal degeneration increased in older patients [17]. Here, we measured CSF T-tau and P-tau across the age span in DS and tested correlations between these markers of AD-like axonal degeneration and markers of $A \beta$ and APP metabolism.

Microglial activation has been suggested to play an important role as a mediator of $A \beta$ toxicity in the development of $\mathrm{AD}$ [22], but to our knowledge no previous study has measured in vivo biomarkers of microglia activity in DS patients. Therefore, we measured the microglial activation markers YKL-40 [23] and CCL2 [24] to determine if they were altered in DS and if they correlated with $A \beta$ or APP levels.

Finally, DS patients may present a variety of neurological symptoms, including sleep dysregulation [12-14], and it has not been studied previously if this is related to $A \beta$ pathology. Recently, it was shown that the neuropeptide orexin, which has key functions in sleep regulation [25], may regulate $A \beta$ dynamics, and it was proposed that it may play a role in the pathogenesis of $\mathrm{AD}[26,27]$. It has further been shown that there is a relationship between $\mathrm{AD}$ pathology and orexin. The final goal of this study was therefore to determine orexin-A levels in DS CSF and to test if orexin-A levels correlated with A $\beta$ or APP levels.

\section{Subjects and Methods}

\section{Subjects}

Lumbar CSF from persons with DS (6 women and 6 men, mean age at lumbar puncture $41 \pm 11$ years) was collected in the Vaalijala Hospital in Pieksämäki, Finland, as described before [17]. Lumbar CSF samples from age- and gender-matched control individuals from the Surgical Stress Study ( 8 women and 12 men, mean age at lumbar puncture $40 \pm 15$ years) were selected as the control group [28]. The study was approved by the local ethics committee of the Kuopio University Hospital and the ethics committee of the University of Gothenburg. Written informed consent was obtained from all participants included in the control group, and detailed information about the study was given to the participants and their caregivers and written informed consent for participation in the study was obtained from them. 
Immunoassays against $A \beta$ Species, sAPP $\alpha / \beta$, T-Tau and

P-Tau

CSF was analyzed for $\mathrm{A} \beta \mathrm{X}-38, \mathrm{~A} \beta \mathrm{X}-40, \mathrm{~A} \beta \mathrm{X}-42$, sAPP $\alpha$ and sAPP $\beta$ [limit of quantification: 8.2, 27.4, 8.2, 31.2 and $31.2 \mathrm{pg} / \mathrm{ml}$, respectively; intra-assay coefficient of variation $(\mathrm{CV}): 4,7,1,4$ and $1 \%$, respectively] using the Meso Scale Discovery (MSD) A $\beta$ Triplex assay for the A $\beta$ peptides and the MSD sAPPa/sAPP $\beta$ multiplex assay for the SAPP domains as described by the manufacturer (MSD, Gaithersburg, Md., USA).

The CSF T-tau concentration was determined using a sandwich ELISA (INNOTEST ${ }^{\circledR}$ hTAU Ag, Innogenetics, Ghent, Belgium) specifically constructed to measure all tau isoforms irrespective of phosphorylation status, as previously described (intra-assay CV 7\%) [29]. Tau phosphorylated at threonine 181 was measured using a sandwich ELISA method [INNOTEST PHOSPHO-TAU(181P), Innogenetics], as previously described (intra-assay CV 2\%) [30]. CSF A $\beta 1-42$ levels were determined using a sandwich ELISA [INNOTEST $\beta$-AMYLOID(1-42), Innogenetics] specifically constructed to measure $A \beta$ containing both the 1st and 42nd amino acid, as previously described (intra-assay CV 7\%) [31]. In this assay, the monoclonal antibody $21 \mathrm{~F} 12$, which is highly specific for the $\mathrm{C}$ terminus of $\mathrm{A} \beta 42$, was used for capture, and 3D6, which is specific to the $\mathrm{N}$ terminus, was used as detector.

\section{Microglial Activation Markers}

CSF levels of YKL-40 (limit of quantification 6,250 pg/ml, intra-assay CV 5\%) were analyzed with a commercial ELISA (R\&D Systems, Minneapolis, Minn., USA), and levels of CCL2 (limit of quantification $0.61 \mathrm{pg} / \mathrm{ml}$, intra-assay CV 14\%) were measured with the MSD human MCP-1 Ultra-Sensitive Kit (MSD). Both markers were analyzed as described by the manufacturer.

\section{Orexin-A}

Orexin-A was measured using an in-house RIA. In brief, $50 \mu \mathrm{l}$ of CSF from control and DS samples were diluted with $200 \mu \mathrm{l}$ of assay buffer $(0.01 \mathrm{M}$ sodium phosphate buffer, $\mathrm{pH} 7.4$, containing $0.15 \mathrm{M} \mathrm{NaCl}, 0.3 \%$ bovine serum albumin, $0.1 \%$ Triton $\mathrm{X}-100$ and 0.001 M EDTA). Calibrators (Orexin-A human PolyPeptide Sc 1337) and diluted samples $(100 \mu \mathrm{l}$ each) were incubated with 100 $\mu \mathrm{l}$ of orexin-A rabbit antiserum (Sigma O9756), final dilution $1 / 350,000$ in assay buffer, at $2-8^{\circ} \mathrm{C}$ for $24 \mathrm{~h}$.

A second incubation was performed in the same manner or at $2-8^{\circ} \mathrm{C}$ for $24 \mathrm{~h}$ after addition of $100 \mu \mathrm{l}$ of ${ }^{125} \mathrm{I}$-orexin-A (diluted to $10,000 \mathrm{cpm} 10 \%$ in assay buffer). Radioactive ligand ( ${ }^{125} \mathrm{I}$-orexinA) was synthesized using a modified chloramine-T method [32], purified with reverse-phase HPLC using a $\mu$-Bondapak C18 column $(3.9 \times 300$ mm, $125 \AA$, $10 \mu \mathrm{m}$, Waters Code Mo. 27324), diluted $1 / 10$ in $\mathrm{CH}_{3} \mathrm{CN}$ and stored at $-20^{\circ} \mathrm{C}$ until use.

Free and bound tracers were separated by adding $200 \mu \mathrm{l}$ of $2 \%$ normal rabbit serum (Sigma R9133; in 0.01 M sodium phosphate buffer, $\mathrm{pH}$ 7.4), $100 \mu$ l of goat anti-rabbit IgG (GAK Sigma R0881; in sodium phosphate buffer, $\mathrm{pH} 7.4$ ) and $500 \mu \mathrm{l}$ of $6 \%$ polyethylene glycol solution (molecular weight 6,000 ; in sodium phosphate buffer, $\mathrm{pH} 7.4)$ before incubation $\left(21^{\circ} \mathrm{C}, 10 \mathrm{~min}\right)$ and centrifugation $\left(1,500 \mathrm{~g}, 21^{\circ} \mathrm{C}, 10 \mathrm{~min}\right)$.

The supernatant was discarded and the precipitate measured in an automatic gamma counter (Wizard 1470; counting efficiency $75 \%$ ) connected to an immunoassay software program (MultiCalc Advanced, Wallac Oy, Finland).
The intra-assay CV and interassay CV for CSF samples at 320 and $801 \mathrm{pg} / \mathrm{ml}$ were both $<6 \%$. The RIA was performed with duplicates of calibrators, controls and samples.

\section{Statistical Methods}

Due to nonnormal distributions for some of the analytes, the group comparisons were made using the nonparametric MannWhitney U test, and correlations are presented as Spearman's $\rho$. Correlations with age were tested by using age both as a continuous and binary variable (with groups dichotomized into subjects younger and older than 40 years). Prism 6 (GraphPad Software, La Jolla, Calif., USA) was used for all statistical analyses. Due to the discovery nature of this study, $p$ values were not corrected for multiple comparisons. The results were considered significant if $\mathrm{p}<$ 0.05 (two-tailed).

\section{Results}

\section{CSF Levels of Biomarkers in DS Patients and Controls}

We initially compared biomarker levels between DS patients and controls. The concentrations of $\mathrm{A} \beta \mathrm{X}-40$, sAPP $\alpha$ and $\mathrm{sAPP} \beta$ were significantly increased $(\mathrm{p}=$ $0.048,0.015$ and 0.036 , respectively) in DS patients, while $A \beta X-38, A \beta X-42$ and $A \beta 1-42$ were similar across the two groups (fig. 1a-f). The axonal damage markers T-tau and P-tau (fig. 1g, h) and the microglia activity markers CCL2 and YKL-40 were also similar between the two groups (fig. 1i, j). The levels of orexin-A were reduced in DS patients $(\mathrm{p}=0.0007$; fig. $1 \mathrm{k})$. Table 1 shows the demographic and biomarker characteristics of DS patients and controls.

\section{Correlation of Biomarkers with Age}

In the DS group, the concentration of $A \beta 1-42$ correlated negatively with age $\left(r_{s}=-0.69, p=0.015\right)$, while Ttau had a positive correlation with age $\left(\mathrm{r}_{\mathrm{s}}=0.68, \mathrm{p}=\right.$ 0.025 ; fig. 2a). YKL-40 correlated positively with age for both DS patients $\left(\mathrm{r}_{\mathrm{s}}=0.76, \mathrm{p}=0.0062\right)$ and controls $\left(\mathrm{r}_{\mathrm{s}}=\right.$ $0.50, p=0.024$; fig. $2 a)$. None of the other markers correlated with age. In figure 3 , scatterplots show the distribution of the markers.

Next we compared biomarker levels between old ( $>40$ years) and young ( $<40$ years) subjects. For the controls (age $\leq 40$ years, $n=13$; age $>40$ years, $n=7$ ), no statistical differences were observed between the groups. However, older DS patients (age $\leq 40$ years, $n=6$; age $>40$ years, $n=6$ ) had significantly increased levels of $T$ tau, P-tau and YKL-40 compared to younger DS patients $(\mathrm{p}=0.0087,0.046$ and 0.015 , respectively; fig. $1 \mathrm{~g}-\mathrm{i})$. None of the other markers differed between young and old DS patients. 


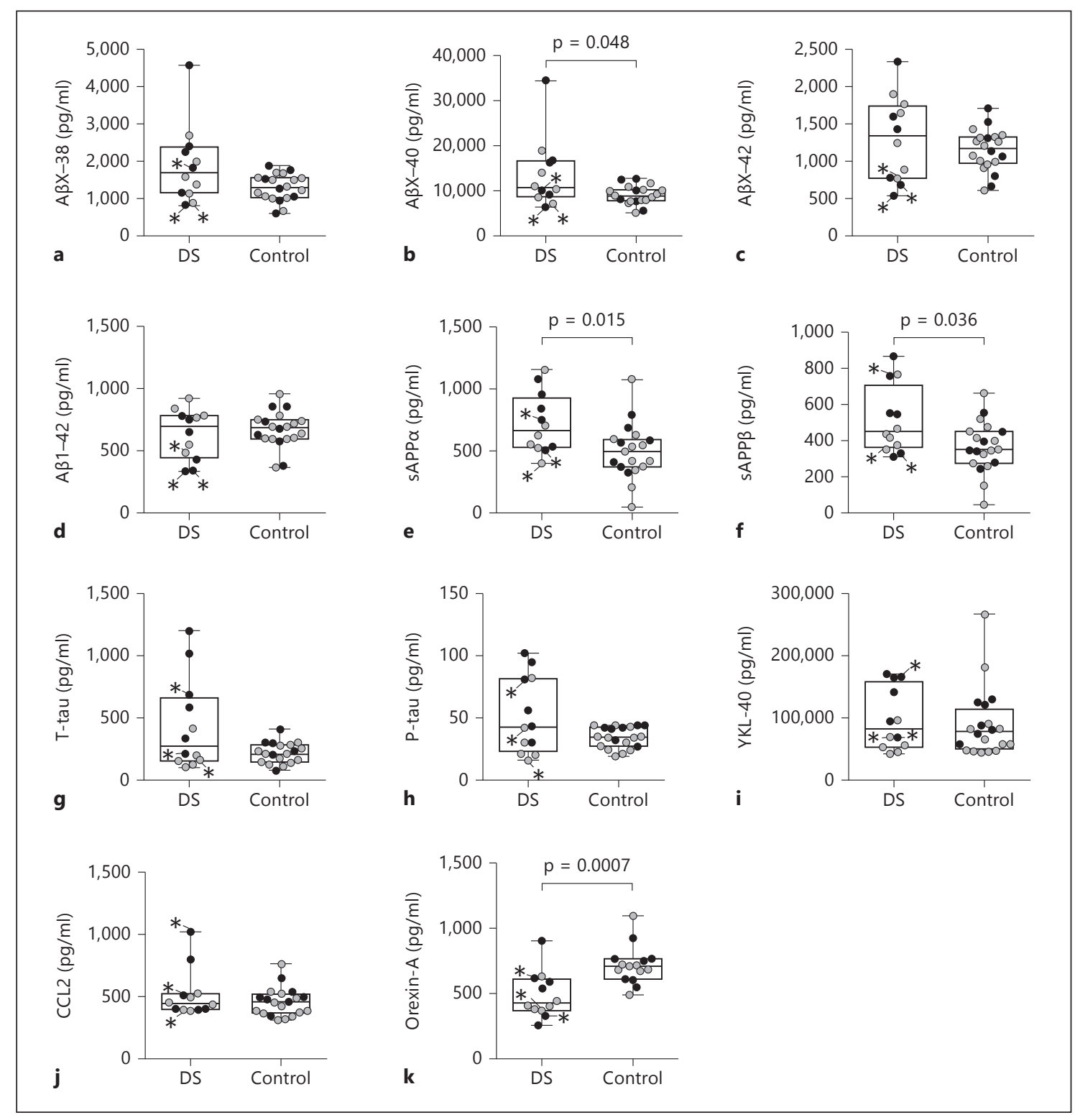

Fig. 1. a-k Scatter plots displaying all markers analyzed. Black circles represent individuals aged $>40$ years old, and grey circles represent individuals aged $\leq 40$ years old. Asterisks denote DS patients with a clinical history indicating dementia.

\section{Correlations of Microglial Activation Markers with}

Other Biomarkers

The concentrations of YKL-40 measured in DS patients had a significant correlation with T-tau $\left(\mathrm{r}_{\mathrm{s}}=0.84\right.$, $\mathrm{p}=0.0022)$ and $\mathrm{P}$-tau $\left(\mathrm{r}_{\mathrm{s}}=0.74, \mathrm{p}=0.0082\right.$; fig. $\left.2 \mathrm{~b}\right)$, while CCL2 did not correlate with either of these markers (fig. 2c). There were no correlations of microglia markers with other biomarkers in controls.

\section{Correlations of Orexin-A with Other Biomarkers}

We found a significant correlation between orexin-A and $A \beta X-38$ and $A \beta X-40$ in both controls $\left(r_{s}=0.78\right.$ and 0.58 , respectively) and DS patients $\left(\mathrm{r}_{\mathrm{s}}=0.85\right.$ and 0.78 , respectively), while $\mathrm{A} \beta \mathrm{X}-42$ only correlated with orexin-A in the control group $\left(r_{s}=0.56\right.$; fig. $\left.2 \mathrm{~d}\right)$. We also found a strong correlation of orexin-A with sAPP $\alpha, s A P P \beta$ and T-tau in the DS group $\left(\mathrm{r}_{\mathrm{s}}=0.81,0.87\right.$ and 0.72 , respectively) but not in the controls. 


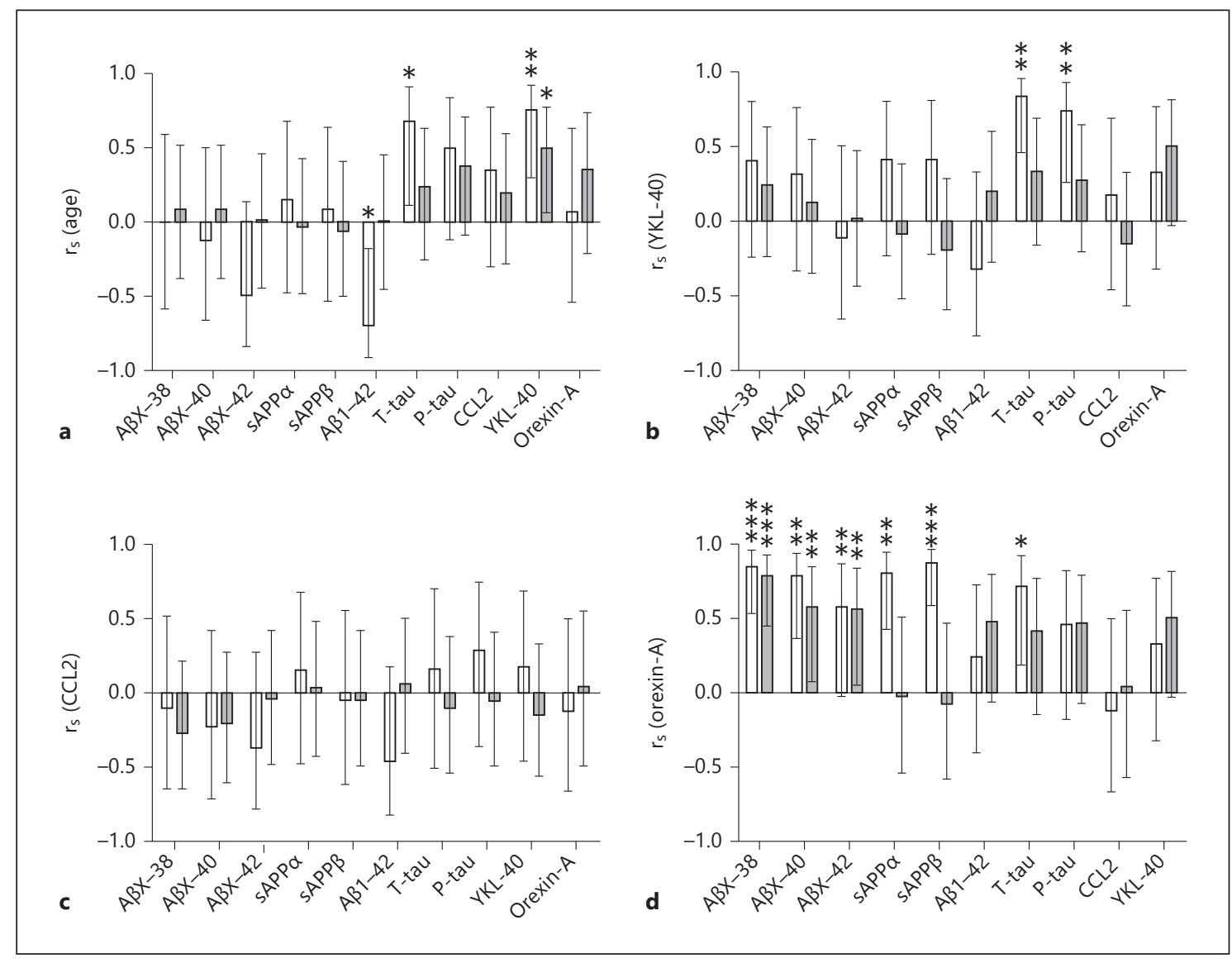

Fig. 2. Correlation coefficients $\left(r_{s}\right)$ for age (a), YKL-40 (b), CCL2 (c) and orexin-A (d) in relation to each biomarker. Open bars represent DS patients, and grey bars represent healthy controls. The error bars display $95 \%$ confidence intervals. ${ }^{*} \mathrm{p}<0.05,{ }^{* *} \mathrm{p}<0.01,{ }^{* * *} \mathrm{p}<0.001$.

Table 1. Demographic and biomarker characteristics of DS patients and controls

\begin{tabular}{lcc}
\hline Characteristic & $\begin{array}{l}\text { Controls } \\
(\mathrm{n}=20)\end{array}$ & $\begin{array}{l}\text { DS patients } \\
(\mathrm{n}=12)\end{array}$ \\
\hline Female/male (\% female) & $8 / 12(33 \%)$ & $6 / 6(50 \%)$ \\
Age at LP, years & $40 \pm 15$ & $41 \pm 11$ \\
A $\beta \mathrm{X}-38, \mathrm{pg} / \mathrm{ml}$ & $1,295 \pm 359$ & $1,892 \pm 1046$ \\
$\mathrm{~A} \beta \mathrm{X}-40, \mathrm{pg} / \mathrm{ml}$ & $9,014 \pm 2,036$ & $13,583 \pm 7,669$ \\
$\mathrm{~A} \beta \mathrm{X}-42, \mathrm{pg} / \mathrm{ml}$ & $1,147 \pm 280$ & $1,300 \pm 572$ \\
$\mathrm{~A} \beta 1-42, \mathrm{pg} / \mathrm{ml}$ & $674 \pm 145$ & $637 \pm 201$ \\
sAPPa, pg/ml & $496 \pm 216$ & $718 \pm 242$ \\
sAPP $\beta, \mathrm{pg} / \mathrm{ml}$ & $362 \pm 140$ & $512 \pm 189$ \\
T-tau, pg/ml & $210 \pm 87$ & $431 \pm 369$ \\
$\mathrm{P}-\mathrm{tau}, \mathrm{pg} / \mathrm{ml}$ & $34 \pm 8.8$ & $52 \pm 31$ \\
CCL2, pg/ml & $457 \pm 114$ & $519 \pm 196$ \\
YKL-40, pg/ml & $89,648 \pm 55,000$ & $97,381 \pm 50,202$ \\
Orexin-A,pg/ml & $716 \pm 146$ & $488 \pm 178$ \\
\hline
\end{tabular}

Values represent means $\pm \mathrm{SD} . \mathrm{LP}=$ Lumbar puncture.

\section{Discussion}

This is the first study systematically testing multiple CSF biomarkers for A $\beta$ pathology, axonal degeneration, microglial activity and sleep dysregulation in patients with DS. The major findings were that (1) levels of $A \beta X-$ 40 , sAPP $\alpha$ and sAPP $\beta$ were significantly increased in DS patients compared to controls; (2) A $\beta 1-42$ decreased with age, and T-tau and P-tau increased with age in DS patients, while the microglia marker YKL-40 increased with age in both DS patients and controls; (3) YKL-40 levels were increased in DS patients with signs of AD-like axonal injury, and (4) the sleep-regulating peptide orexin-A was significantly reduced in DS patients compared to controls and was related to CSF levels of several $A \beta$ and sAPP peptides in both DS patients and controls, as well as to signs of axonal injury in DS patients. Taken together, these results support the amyloid cascade hypothesis 


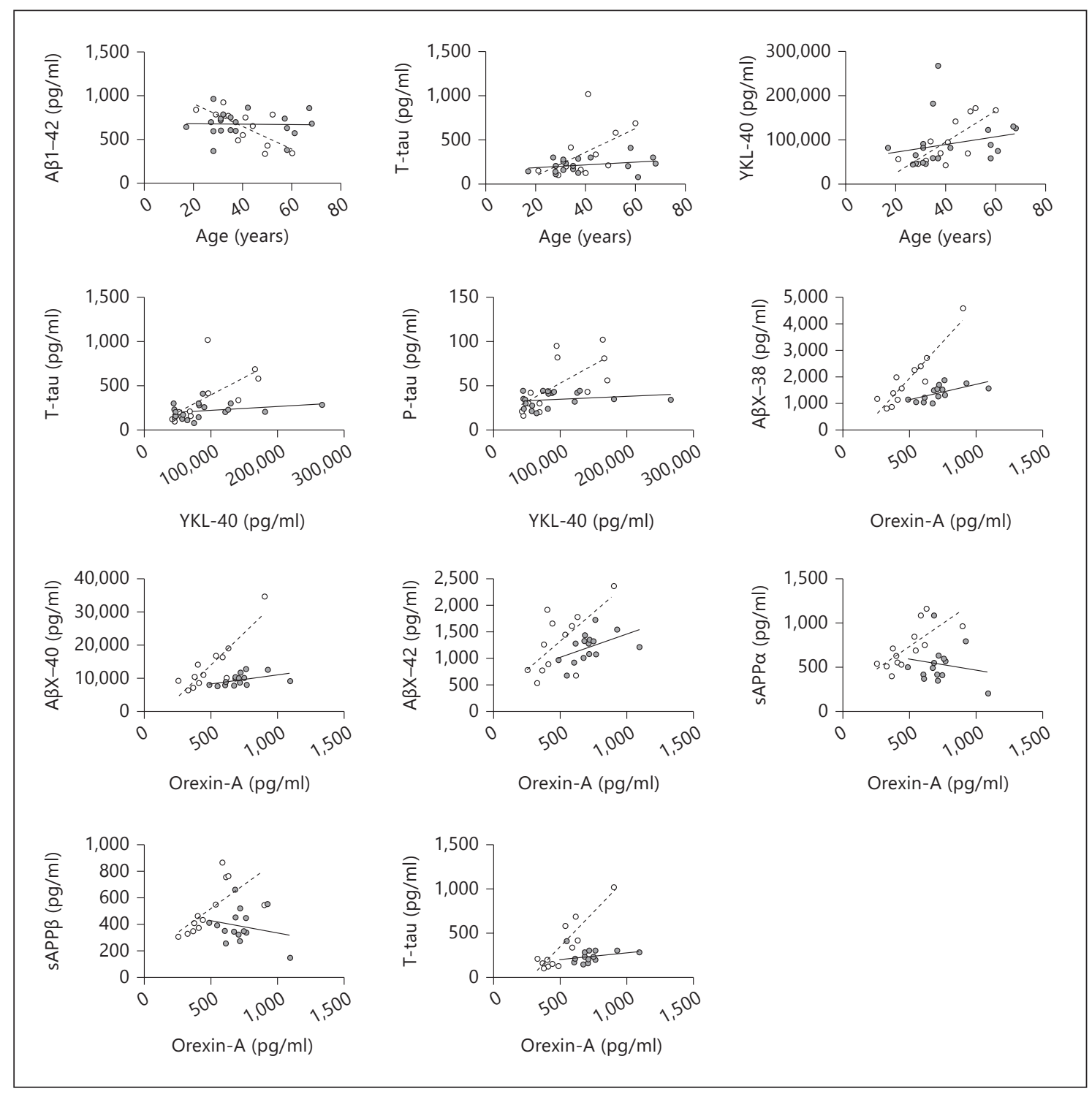

Fig. 3. Scatter plots displaying the distributions of the markers with $\mathrm{p}<0.05$. Open circles represent DS patients, and grey circles represent healthy controls.

by confirming that persons with DS have a lifelong overproduction of APP, while plaque pathology, axonal degeneration and microglia activation is present mainly in older subjects. The results also indicate dramatic effects of DS on the sleep-regulating peptide orexin-A and suggest that this is related to $A \beta$ metabolism and axonal degeneration.

The finding that levels of A $\beta X-40$, sAPP $\alpha$ and sAPP $\beta$ were significantly increased in DS patients compared to controls agrees with an overproduction of APP due to the extra copy of chromosome 21 in DS. Furthermore,
CSF A $\beta 1-42$ levels correlated inversely with age in DS, indicating late-life $\mathrm{A} \beta$ plaque pathology development, replicating findings from an earlier study [17]. A study on carriers of genetic mutations causing autosomal dominant $\mathrm{AD}$ found increased CSF $\mathrm{A} \beta 1-42$ in subjects about 2 decades before expected symptom onset [33]. This is a finding we could not replicate; there was considerable overlap for CSF $A \beta X-42$ and CSF $A \beta 1-42$ between young $(<40$ years) DS patients and controls (fig. 2c, d, grey bars). It is possible that an investigation directed specifically at very young patients and controls 
(in their 20s) could identify elevated CSF A $\beta 42$ in very young DS patients. None of the other APP-related markers correlated with age, suggesting that levels of these markers are unaffected by the presence of $A \beta$ pathology. The microtubule-associated protein $\mathrm{T}$-tau showed a significant correlation with age, with clearly increased levels in the older DS individuals, for both T-tau and P-tau, resembling the evolution of biomarker changes in $\mathrm{AD}$ [34].

Microglial activation has been associated with $\mathrm{AD}$, and it has been suggested that microglia and astrocytes contribute to $\mathrm{AD}$ progression $[35,36]$. Recently, it was shown that the microglial activation marker YKL-40 was elevated in $\mathrm{AD}$ compared to controls $[37,38]$. Here, we found a correlation between the levels of YKL-40 and age in both DS and control individuals, with clearly increased levels in the older DS patients. Relatively little is known about inflammation and microglial activation in the DS brain, but there are a number of different inflammatory genes on chromosome 21 which may induce neuroinflammation in DS [39]. YKL-40 also correlated with Ttau and P-tau in DS patients, indicating an association between neuronal damage and microglial activation. Our findings support the presence of microglial activation in $\mathrm{DS}$ patients with $\mathrm{AD}$-like neuronal injury and support the use of YKL-40 as a readout for this phenomenon in clinical research [38].

The second inflammatory marker studied here, CCL2, has been suggested to be a predictive indicator for the appearance or severity of $\mathrm{AD}$. However, CCL2 results in $\mathrm{AD}$ are conflicting; one study showed increased CSF levels in $\mathrm{AD}$ [40], but another could not replicate this finding [41]. We could not find any association between CCL2 and age, or differences between DS and controls. Further, there was no correlation between YKL-40 and CCL2 (fig. 2b). The different associations for YKL- 40 and CCL2 are consistent with a previous report from our laboratory [41], where YKL-40 and CCL2 did not correlate in healthy controls or AD patients, although they correlated in patients with other dementias. There are several possible explanations for these differences in associations. For example, it is possible that CSF levels of YKL40 and CCL2 do not only represent brain microglial activity but also other pathological processes, which may be differently regulated in different conditions. Alternatively, the release of YKL-40 and CCL2 may depend on specific states of microglia activity, or there may be differences in their biological turnover time, distorting the associations. However, we suggest that the present data, together with previous publications, argue against the use of CCL2 to monitor microglial activation in neurodegenerative diseases.

To our knowledge, orexin-A, which is a key molecule in sleep regulation $[42,43]$, has never been measured previously in DS patients. Its association with sleep regulation and narcolepsy is well established, and it has also been implicated in other neurological disorders [for a review, see 44]. Information regarding sleep was not available for the subjects included in the study, but sleep problems in DS are common and well described [12-14]. Our finding that DS patients have reduced CSF orexin-A levels provides novel evidence of altered orexin-A regulation in DS. Furthermore, we found that orexin-A correlated with $\mathrm{A} \beta \mathrm{X}-38 / 40 / 42$ in both DS patients and control individuals, and with sAPP $\alpha$ and sAPP $\beta$ in DS, but not with A $\beta 1-$ 42 in either group. These findings confirm and add to previous studies describing associations between $A \beta$ and sleep regulation [45]. A few studies have examined associations between orexin- $A$ and $A \beta$, with somewhat conflicting results. One study in rodents showed that the levels of $A \beta$ in brain interstitial fluid correlated with wakefulness and increased significantly during acute sleep deprivation and during orexin-A infusion [26]. Another study showed that the levels of orexin-A in postmortem ventricular CSF was lower in $\mathrm{AD}$ patients compared to controls [46]. In contrast, one study found increased levels of CSF orexin-A in (female) AD patients but no associations between $A \beta 1-42$ and orexin- $A$ in CSF [47]. The correlations identified in this study between CSF orexin$A$ and several different $A \beta$ and sAPP peptides suggest that orexin-A expression is coupled to APP production and/ or degradation but not to the presence of amyloid plaques.

A limitation of this study was the large number of statistical tests performed, increasing the risk of type I statistical errors. Due to the discovery nature of the study, we did not correct for multiple comparisons. However, for most key findings, multiple consistent associations were identified, supporting the main conclusions. The results of this discovery study should be validated in independent cohorts.

In summary, we found evidence of increased $A \beta$ production at an early age in DS and development of $A \beta$ plaque pathology later in life. We also found biomarker evidence of microglial activation in DS, and this activation correlated with the presence of AD-like axonal injury. Finally, we found reduced levels of the sleep-regulating peptide orexin-A in DS and evidence that this protein may be coordinated with APP metabolism. These findings from DS may increase our understanding of disease processes leading to $\mathrm{AD}$. 


\section{Acknowledgements}

This study was supported by the Swedish Research Council (project No. 14002, K2010-63P-21562-01-4, K2011-61X-2040105-6), the Knut and Alice Wallenberg Foundation, Stiftelsen Gamla Tjänarinnor, Magn. Bergvalls Stiftelse, Gun och Bertil Stohnes
Stiftelse, the Swedish Brain Fund, the Alzheimer Foundation, Sweden, the Dementia Association, Sweden, the Wenner-Gren foundation, the JPND Project BIOMARKAPD, Göteborgs Läkaresällskap, Svenska Läkaresällskapet, Sahlgrenska Universitetssjukhuset, Carl-Bertil Laurells fond and Klinisk Biokemi i Norden.

\section{References}

1 Down J: Observations on an ethnic classification of idiots. London Hospital Reports 1866; 3:259-262.

$>2$ Lemere CA, Blusztajn JK, Yamaguchi H, Wisniewski T, Saido TC, Selkoe DJ: Sequence of deposition of heterogeneous amyloid betapeptides and APO E in Down syndrome: implications for initial events in amyloid plaque formation. Neurobiol Dis 1996;3:16-32.

$>3$ Leverenz JB, Raskind MA: Early amyloid deposition in the medial temporal lobe of young Down syndrome patients: a regional quantitative analysis. Exp Neurol 1998;150:296-304.

4 Prasher VP, Farrer MJ, Kessling AM, Fisher EM, West RJ, Barber PC, Butler AC: Molecular mapping of Alzheimer-type dementia in Down's syndrome. Ann Neurol 1998;43:380383.

5 Bush A, Beail N: Risk factors for dementia in people with Down syndrome: issues in assessment and diagnosis. Am J Ment Retard 2004; 109:83-97.

6 Blennow K, de Leon MJ, Zetterberg H: Alzheimer's disease. Lancet 2006;368:387-403.

7 Malamud N: Neuropathology of organic brain syndromes associated with aging; in Gaitz C (ed): Aging and the Brain. Adv Behav Biol, vol 3, Springer, 1995, pp 63-87.

8 Goldgaber D, Lerman MI, McBride OW, Saffiotti U, Gajdusek DC: Characterization and chromosomal localization of a cDNA encoding brain amyloid of Alzheimer's disease. Science 1987;235:877-880.

9 Robakis NK, Ramakrishna N, Wolfe G, Wisniewski HM: Molecular cloning and characterization of a cDNA encoding the cerebrovascular and the neuritic plaque amyloid peptides. Proc Natl Acad Sci USA 1987;84 4190-4194.

10 Tanzi RE, Gusella JF, Watkins PC, Bruns GA, St George-Hyslop P, Van Keuren ML, Patterson D, Pagan S, Kurnit DM, Neve RL: Amyloid beta protein gene: cDNA, mRNA distribution, and genetic linkage near the Alzheimer locus. Science 1987;235:880-884.

11 Selkoe DJ: Alzheimer's disease: genes, proteins, and therapy. Physiol Rev 2001;81:741766.

-12 Dahlqvist A, Rask E, Rosenqvist CJ, Sahlin C, Franklin KA: Sleep apnea and Down's syndrome. Acta Otolaryngol 2003;123:1094-1097.

13 Diomedi M, Curatolo P, Scalise A, Placidi F, Caretto F, Gigli GL: Sleep abnormalities in mentally retarded autistic subjects: Down's syndrome with mental retardation and normal subjects. Brain Dev 1999;21:548-553.

14 Maas AP, Didden R, Korzilius H, Curfs LM: Exploration of differences in types of sleep disturbance and severity of sleep problems between individuals with Cri du Chat syndrome, Down's syndrome, and Jacobsen syndrome: a case control study. Res Dev Disabil 2012;33:1773-1779.

15 Landau SM, Lu M, Joshi AD, Pontecorvo M, Mintun MA, Trojanowski JQ, Shaw LM, Jagust WJ; Alzheimer's Disease Neuroimaging Initiative: Comparing positron emission tomography imaging and cerebrospinal fluid measurements of $\beta$-amyloid. Ann Neurol 2013;74:826-836.

16 Potter R, Patterson BW, Elbert DL, Ovod V, Kasten T, Sigurdson W, Mawuenyega K, Blazey T, Goate A, Chott R, Yarasheski KE, Holtzman DM, Morris JC, Benzinger TLS, Bateman RJ: Increased in vivo amyloid- $\beta 42$ production, exchange, and loss in presenilin mutation carriers. Sci Transl Med 2013;5: 189 ra177.

17 Tapiola T, Soininen H, Pirttila T: CSF tau and Abeta42 levels in patients with Down's syndrome. Neurology 2001;56:979-980.

-18 Tamaoka A, Sekijima Y, Matsuno S, Tokuda T, Shoji S, Ikeda SI: Amyloid beta protein species in cerebrospinal fluid and in brain from patients with Down's syndrome. Ann Neurol 1999;46:933.

19 Portelius E, Mattsson N, Andreasson U, Blennow K, Zetterberg $\mathrm{H}$ : Novel Abeta isoforms in Alzheimer's disease - their role in diagnosis and treatment. Curr Pharm Des 2011;17: 2594-2602.

20 Holtzman DM, Morris JC, Goate AM: Alzheimer's disease: the challenge of the second century. Sci Transl Med 2011;3:77sr71.

21 Esch FS, Keim PS, Beattie EC, Blacher RW, Culwell AR, Oltersdorf T, McClure D, Ward PJ: Cleavage of amyloid beta peptide during constitutive processing of its precursor. Science 1990;248:1122-1124.

22 Kitazawa M, Yamasaki TR, LaFerla FM: Microglia as a potential bridge between the amyloid beta-peptide and tau. Ann NY Acad Sci 2004;1035:85-103.

23 Bonneh-Barkay D, Bissel SJ, Wang G, Fish KN, Nicholl GC, Darko SW, Medina-Flores R, Murphey-Corb M, Rajakumar PA, Nyaundi J, Mellors JW, Bowser R, Wiley CA: YKL40 , a marker of simian immunodeficiency vi- rus encephalitis, modulates the biological activity of basic fibroblast growth factor. Am J Pathol 2008;173:130-143.

24 Sokolova A, Hill MD, Rahimi F, Warden LA, Halliday GM, Shepherd CE: Monocyte chemoattractant protein-1 plays a dominant role in the chronic inflammation observed in $\mathrm{Al}$ zheimer's disease. Brain Pathol 2009;19:392398.

25 Cao M, Guilleminault C: Hypocretin and its emerging role as a target for treatment of sleep disorders. Curr Neurol Neurosci Rep 2011;11: 227-234.

26 Kang JE, Lim MM, Bateman RJ, Lee JJ, Smyth LP, Cirrito JR, Fujiki N, Nishino S, Holtzman DM: Amyloid-beta dynamics are regulated by orexin and the sleep-wake cycle. Science 2009; 326:1005-1007.

27 Slats D, Claassen JA, Lammers GJ, Melis RJ, Verbeek MM, Overeem S: Association between hypocretin-1 and amyloid-beta42 cerebrospinal fluid levels in Alzheimer's disease and healthy controls. Curr Alzheimer Res 2012;9:1119-1125.

28 Anckarsater R, Vasic N, Jideus L, Kristiansson M, Zetterberg H, Blennow K, Anckarsater H: Cerebrospinal fluid protein reactions during non-neurological surgery. Acta Neurol Scand 2007;115:254-259.

29 Blennow K, Wallin A, Agren H, Spenger C, Siegfried J, Vanmechelen E: Tau protein in cerebrospinal fluid: a biochemical marker for axonal degeneration in Alzheimer disease? Mol Chem Neuropathol 1995;26:231-245.

30 Vanmechelen E, Vanderstichele H, Davidsson P, Van Kerschaver E, Van Der Perre B, Sjogren M, Andreasen N, Blennow K: Quantification of tau phosphorylated at threonine 181 in human cerebrospinal fluid: a sandwich ELISA with a synthetic phosphopeptide for standardization. Neurosci Lett 2000;285: 49-52.

-31 Andreasen N, Hesse C, Davidsson P, Minthon L, Wallin A, Winblad B, Vanderstichele $\mathrm{H}$, Vanmechelen E, Blennow K: Cerebrospinal fluid beta-amyloid(1-42) in Alzheimer disease: differences between early- and lateonset Alzheimer disease and stability during the course of disease. Arch Neurol 1999;56: 673-680.

32 Hunter WM, Greenwood FC: Preparation of iodine-131 labelled human growth hormone of high specific activity. Nature 1962;194: 495-496. 
33 Reiman EM, Quiroz YT, Fleisher AS, Chen K, Velez-Pardo C, Jimenez-Del-Rio M, Fagan AM, Shah AR, Alvarez S, Arbelaez A, Giraldo M, Acosta-Baena N, Sperling RA, Dickerson B, Stern CE, Tirado V, Munoz C, Reiman RA, Huentelman MJ, Alexander GE, Langbaum JB, Kosik KS, Tariot PN, Lopera F: Brain imaging and fluid biomarker analysis in young adults at genetic risk for autosomal dominant Alzheimer's disease in the presenilin 1 e280a kindred: a case-control study. Lancet Neurol 2012;11:1048-1056.

- 34 Jack CR Jr, Knopman DS, Jagust WJ, Petersen RC, Weiner MW, Aisen PS, Shaw LM, Vemuri P, Wiste HJ, Weigand SD, Lesnick TG, Pankratz VS, Donohue MC, Trojanowski JQ: Tracking pathophysiological processes in $\mathrm{Al}$ zheimer's disease: an updated hypothetical model of dynamic biomarkers. Lancet Neurol 2013;12:207-216.

35 Amor S, Puentes F, Baker D, van der Valk P. Inflammation in neurodegenerative diseases. Immunology 2010;129:154-169.

- 36 Glass CK, Saijo K, Winner B, Marchetto MC, Gage FH: Mechanisms underlying inflammation in neurodegeneration. Cell 2010;140: 918-934.
Olsson B, Hertze J, Lautner R, Zetterberg H, Nagga K, Hoglund K, Basun H, Annas P, Lannfelt L, Andreasen N, Minthon L, Blennow K, Hansson O: Microglial markers are elevated in the prodromal phase of Alzheimer's disease and vascular dementia. J Alzheimers Dis 2013;33:45-53.

38 Craig-Schapiro R, Perrin RJ, Roe CM, Xiong C, Carter D, Cairns NJ, Mintun MA, Peskind ER, Li G, Galasko DR, Clark CM, Quinn JF, D'Angelo G, Malone JP, Townsend RR, Morris JC, Fagan AM, Holtzman DM: YKL-40: a novel prognostic fluid biomarker for preclinical Alzheimer's disease. Biol Psychiatry 2010; 68:903-912.

39 Wilcock DM: Neuroinflammation in the aging Down syndrome brain; lessons from $\mathrm{Al}$ zheimer's disease. Curr Gerontol Geriatr Res 2012;2012:170276.

40 Galimberti D, Schoonenboom N, Scarpini E, Scheltens P; Dutch-Italian Alzheimer Research Group: Chemokines in serum and cerebrospinal fluid of Alzheimer's disease patients. Ann Neurol 2003;53:547-548.

41 Mattsson N, Tabatabaei S, Johansson P, Hansson O, Andreasson U, Mansson JE, Johansson JO, Olsson B, Wallin A, Svensson J, Blennow K, Zetterberg H: Cerebrospinal fluid microglial markers in Alzheimer's disease: elevated chitotriosidase activity but lack of diagnostic utility. Neuromolecular Med 2011; 13:151-159.

-42 de Lecea L, Kilduff TS, Peyron C, Gao X, Foye PE, Danielson PE, Fukuhara C, Battenberg EL, Gautvik VT, Bartlett FS 2nd, Frankel WN, van den Pol AN, Bloom FE, Gautvik KM, Sutcliffe JG: The hypocretins: hypothalamusspecific peptides with neuroexcitatory activity. Proc Natl Acad Sci USA 1998;95:322-327.
3 Sakurai T, Amemiya A, Ishii M, Matsuzaki I, Chemelli RM, Tanaka H, Williams SC, Richardson JA, Kozlowski GP, Wilson S, Arch JR, Buckingham RE, Haynes AC, Carr SA, Annan RS, McNulty DE, Liu WS, Terrett JA, Elshourbagy NA, Bergsma DJ, Yanagisawa M: Orexins and orexin receptors: a family of hypothalamic neuropeptides and G protein-coupled receptors that regulate feeding behavior. Cell 1998;92:573-585.

44 Baumann CR, Bassetti CL: Hypocretins (orexins) and sleep-wake disorders. Lancet Neurol 2005;4:673-682.

45 Huang Y, Potter R, Sigurdson W, Santacruz A, Shih S, Ju YE, Kasten T, Morris JC, Mintun M, Duntley S, Bateman RJ: Effects of age and amyloid deposition on abeta dynamics in the human central nervous system. Arch Neurol 2012;69:51-58

46 Fronczek R, van Geest S, Frolich M, Overeem S, Roelandse FW, Lammers GJ, Swaab DF: Hypocretin (orexin) loss in Alzheimer's disease. Neurobiol Aging 2012;33:1642-1650.

-47 Wennstrom M, Londos E, Minthon L, Nielsen HM: Altered CSF orexin and alpha-synuclein levels in dementia patients. J Alzheimers Dis 2012;29:125-132. 